\title{
PERCEPTIONS AND ATTITUDES WITH REGARD TO PUBLIC INTERNATIONAL LAW: empirical evidence from law students in the city of São Paulo' // Marcel Kamiyama ${ }^{2}$
}

\section{Keywords}

international law / teaching methods / empirical survey / Brazil

dIIIIIIIIIIIIIIIIIIIIIIIIIIIIIII

\section{Table of contents}

\section{1}

Introduction: international law in a world of sceptics

2 Methodology

2.1 Research object and tools

2.2 Research progression and potential biases

3 Irrelevant verbiage? Myths about international law among law students

3.1 The myth of international relations

3.2 International law and its relevance in international relations

3.3 Redeeming international law?

3.4 Fourth myths about international law and international relations

3.5 Prevalence of each myth relative to the others

3.6 International law and national interests

3.7 Conclusion: thriving in diversity?

4 Unnecessary hurdle? International law in the legal curriculum and profession

4.1 Professional ambitions among law students

4.2 International law as a law school course

4.3 International law as a professional skill

4.4 Perceptions of how international law is taught and its place in the curriculum

4.5 Conclusion: international law teaching at a crossroads

5 Final conclusions

6 References

\section{Abstract}

This article empirically examines, by means of a survey conducted at four universities in São Paulo, two issues related to the teaching of international law in Brazil: (1) what law students think of the discipline as a material branch of the law (its effectiveness, legitimacy etc.) and (2) what they think of the discipline as a component of the law school curriculum. The first part draws upon the semiological concept of "myth" in order to paint a picture of students' views about the place of international law in the world, as well as upon quantitative data to assess their opinions on compliance with international norms. The second part, which also relies on quantitative and qualitative data, describes students' ideas about how international law should be taught (if at all). The responses show mild student scepticism and dissatisfaction with teaching methods that invite a number of questions for reflection, which are raised in the final part.

1 LL.M. candidate at Harvard Law School.

2 This article is an abridged version of a bachelor's dissertation submitted to the Faculty of Law of the University of São Paulo on 30 September 2016. The research for the dissertation was funded by a grant (Iniciação Científica) from the University of São Paulo in 2015. The author would like to thank Professor Alberto do Amaral Júnior, who supervised this work and fully supported the project. 


\section{PERCEPÇÕES E ATITUDES COM RELAÇÃO AO DIREITO}

INTERNACIONAL PÚBLICO: evidências empíricas de estudantes de direito na cidade de São Paulo // Marcel Kamiyama

\section{Palavras-chave}

Direito internacional/ métodos de ensino/ pesquisa empírica/ Brasil

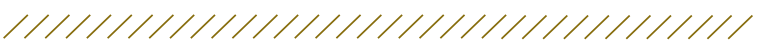

\section{Resumo}

Este artigo examina empiricamente, através de pesquisa com questionários conduzida em quatro universidades em São Paulo, dois temas relativos ao ensino do direito internacional no Brasil: (1) o que pensam os estudantes sobre a disciplina como um ramo material do direito (sua efetividade, legitimidade etc.) e (2) o que pensam sobre a disciplina como um componente do currículo da faculdade de direito. A primeira parte baseia-se no conceito semiológico de "mito" para analisar as visões dos estudantes acerca da posição do direito internacional no mundo, bem como em dados quantitativos para determinar suas opiniões sobre a obediência às normas internacionais. A segunda parte, que também utiliza dados quantitativos e qualitativos, descreve as ideias dos estudantes sobre como o direito internacional deve ser ensinado (se o deve). As respostas mostram leve ceticismo e insatisfação com métodos de ensino que levantam algumas questões para reflexão, que são abordadas na parte final. 


\section{Introduction: international law in a world of sceptics}

There is no lack of men who view this branch of law with contempt as having no reality outside of an empty name. On the lips of men quite generally is the saying of Euphemus, which Thucydides quotes, that in the case of a king or imperial city nothing is unjust which is expedient. Of like implication is the statement that for those whom fortune favours might makes right, and that the administration of a state cannot be carried on without injustice. (Grotius 1925:9)

Grotius's words were tailored for his age, an early modern Europe going through the growing pains of mercantilist capitalism and grappling with the end of the medieval world and its mindset. Yet this bleak assessment of international law's place in the popular imagination might as well have come from the pen of an international lawyer today, the vexatious apprehension about the discipline being a unifying thread between past and present3. The millennial tradition of realism has cast a long shadow over international law since its inception (Steinberg 2013:150), and especially after the Second World War, when so-called "idealists" were forced into retreat due to the sheer weight of circumstances (Koskenniemi 2012:8). Generally, it is safe to assume that there is hardly a student in our field who has not been sneered at for being a "lofty utopian" in the very cradle of realpolitik. The sentiments of doubt and insecurity seem to cut across the boundaries of time and space.

That the pessimism of a 370-year-old quote resonates with twenty-first century international legal scholars is a monument to the discipline's low self-esteem. The academic realism just described has an ideological alter ego in the vernacular: a political view to the effect that international law is just "empty talk" 4 . International law is also assaulted from the outside, by

3 In Brazilian international legal scholarship, two examples are Celso de Albuquerque Mello who, in a preface to an international law treatise, notes that "Brazilians still do not know the importance of international law" (Mello 2004:3), and Antônio Augusto Cançado Trindade (Trindade 2002:9), who laments that the discipline is considered as a non-priority by technicians and is regarded with indifference. 4 As a British international lawyer put it, "Too many people assume, generally without having given any serious thought to its character or its history, that international law is and has always been a sham" (Brierly 1944:1) the Machiavellian layman who revels in his black-andwhite castigation of all things "naïve" (as opposed to "concrete" hard power). International lawyers unfailingly retort that might does not make right, thereby dutifully imitating the age-old pattern of international law argument between apology and utopia (Koskenniemi 2005).

It would seem that we are forever fated to re-enact the seesaw of our intellectual forebears, interspersing crude "realism" with bouts of "idealism" when disaster strikes. But is the "realist consensus" real in legal academia in the first place? Propelled by this question, we explore in this article the perceptions (subjective views) and attitudes (reactions to a given proposition) that law students have in relation to international law. We want to penetrate the deeper layers of the commonplace inkling that law students dismiss international law as a feeble constellation of unachievable ideals. This is an essential step to broadening our horizons in elucidating problems such as why international law plays a relatively minor role in Brazilian legal institutions5 -, and how legal education should be rethought if we are to escape from realist or moralistic platitudes when it comes to addressing the discipline. Additionally, this question is indissociable from the ongoing debate in Brazilian legal academia over curriculum reform (should we be less positivistic?).

Another intuition we wish to put to the test is the idea that students' perceptions of international law as a law school subject and as a professional skill are mainly negative. We would suggest this is another commonly held belief shared by professors and students alike. As an anecdotal example, in 2010, the University of São

5 In a fascinating empirical take on the diffusion of international law in the Brazilian judiciary, Cunha (2010:152-154) found that 59\% of judges at the Rio de Janeiro State Court had but a superficial grasp of the international human rights protection system, and $20 \%$ were not familiar with the mechanisms at all. International human rights case-law also remains a mystery to most adjudicators: $56 \%$ claimed to be moderately acquainted with court decisions, $21 \%$ said that they rarely get hold of information on these, $10 \%$ are completely ignorant of the topic, and a meagre $13 \%$ said to be well-informed on developments. This adds up to a vast majority of judges not having a sufficient command of international human rights law. However, the most sobering reminder of international law's status (or, at least, that of international human rights law) in Brazil is the fact that $66 \%$ of judges maintained never to have applied the American Convention on Human Rights to a case. 
Paulo's (USP) international law student society indignantly noted in its welcome package for freshmen that international law is routinely scoffed at as "perfumaria jurídica" - literally, "legal perfumery”, meaning that it is superfluous as a law school module - before vigorously rejecting this by stressing how international law permeates all corners of the legal profession. The assumption is that students see international law as academically irrelevant and professionally useless. These questions are, of course, closely linked to the previous one: the (lack of) prestige of international law as a branch of law trickles down to its reputation in academia and the profession.

These are, then, our two research questions: (i) does empirical evidence support the apparently commonly held assumption that law students hold a "realist" view of the world in which international law plays no significant role?; and (ii) to what extent are students' perceptions about international law in the law school curriculum and as a professional skill negative? We delineate our ideas further in the sections below, but here it suffices to say that this is an endeavour in interdisciplinary empirical research. Although IR-based interdisciplinary approaches have stolen the spotlight in recent years, little time has been devoted to the lawyers themselves, and, in particular, how they are educated.

International law, as an argumentative practice realised through technical discourse, is brought into being primarily by lawyers, the social caste to which its socially-constructed discursive monopoly belongs (Goldstein 1984:175). The forms it takes depend on the attitudes of the profession; to change the education of lawyers, and consequently the profession, is to change the law (Kennedy 1998:54). Lawyers sit as judges in cases concerning the application of international law, advise foreign ministries on treaties and the conduct of international affairs, and counsel clients, national or otherwise, on a myriad of legal conundrums. In these activities, ideological input is a preponderant factor, as Posner (2010:13) points out in relation to judicial work. This has very concrete repercussions in the creation and enforcement of international law. Knowing the perceptions that students have about the discipline and its teaching is indispensable in diagnosing what sort of lawyers law schools are edu- cating, and from there, prescribing a solution for this predicament, if any exists or is needed.

Our objective is to offer a contribution by describing the perceptions and attitudes of law students from selected universities in São Paulo. The two pillars of this essay, as explained above, are: the perceptions and attitudes of law students with regard to international law, and the perceptions and attitudes of law students with regard to international law in the legal curriculum and in the legal profession.

For the first, the analytical category that we employ is that of myth. The myth is a semiological concept coined by Roland Barthes (1970:224) that refers to a specific use of language whereby multiple strata of signification are laid over the primary sense of words in order to create alternative apparent truths based on the conveyor's ideology. However, on top of this epistemological substratum, we give the concept a more sociological connotation, and use it as an ideal type to describe students' perceptions and attitudes. The myths are derived chiefly from qualitative data, but quantitative data also complement the analysis throughout to give a numerical look at the interpretation of the respondents' words.

In a nutshell, we have identified four myths: the sovereigntist-regulatory (a largely liberal story about international law regulating relations between equal sovereigns); the materialist-determinist (a Marxist-realist story about a frail international law cowed into irrelevance by power struggles); the value-proselytist (a story about the spread of "Western" values and ideas); and the complex-globalist (a story about seismic changes in the world that have done away with old ways of interacting and conceptualising international relations). They reflect the gamut of ways of interpreting the world that float around the political universe.

The second pillar of our research concerns students' perceptions of international law as a module in the legal curriculum and as a skill in legal practice. While we do identify scepticism among some, most respondents acknowledge that it is a relevant body of knowledge for a career in law and that it should be taught to some extent at law schools, and would study it even if it were an elective. However, this is accompanied by 
criticism of the methodology and the course content.

This article is mainly descriptive, and establishing relations of causality largely falls outside the ambit of this inquiry. Needless to say, each of these lines of work entails different approaches, and it is therefore to the topic of method that we dedicate the next few paragraphs (2). The following section contains a description in broad strokes of the theoretical framework centred on the concept of myth (of international relations) that is the backbone of the first research question of this piece, and then proceeds to dissect the empirical findings in light of this (3). The same is done in relation to the empirical results for the second research question in the following section (4). Last but not least, we recapitulate the essence of the principal argument resulting from the research and draw some tentative conclusions as to the current state of international law teaching in the country (5).

\section{Methodology}

\subsection{Research object and tools}

Before turning to the empirical data, a cursory review of the research object and method adopted here is in order. As regards the first, because of time and resource constraints the target group had to be narrowed down to four law schools, all located in the city of São Paulo and topping the national rankings for bar exam performance and post-graduation employment rates (Folha de São Paulo 2013): USP, the Pontifical Catholic University of São Paulo (PCU), the Mackenzie Presbyterian University (MPU) and the Getúlio Vargas Foundation (GVF). Obviously, this has important consequences for the scope of the results: this sample cannot represent the totality of law students in the city of São Paulo, let alone Brazil. Moreover, since entry to these universities is competitive and, apart from tuition-free USP, fees are considerably above the national average, these institutions cater for a rather limited social stratum. That being said, while we do not claim to extend the validity of this study's conclusions beyond the schools visited, they may suggest new directions for visualising the role of international law in the academy and legal profession.

At USP, public international law is split into two com- pulsory 30-hour modules for second- and third-year students: "Direito Internacional Público I" (Public International Law I) and "Direito Internacional Público II" (Public International Law II). The same occurs at PCU, with the difference that the number of contact hours for each module is 28 . On the other hand, at MPU there is a single 48-hour course for public international law. Lastly, GVF has an unorthodox structure: instead of the usual "public international law" and "private international law" duo, all transnational legal matters are combined into two eclectic courses of 60 hours each: "Ordem Jurídica Internacional" (International Legal Order) and "Direito Internacional Econômico" (International Economic Law).

The main instrument for data collection was a pretested questionnaire that was administered to 1,300 students, sampled (Epstein and Martin 2014) so as to represent the wider make-up of the universities above. The return rate was $100 \%$ - aided by the fact that the survey was conducted in person during class time with the consent of the individual lecturer and each college dean -, and the response percentage was close to that number (specific figures will be indicated when pertinent). Furthermore, seeing as our goal is to observe the mentality of law students (i.e. those who are immersed in legal logic as much as possible), we deliberately excluded people for whom law was not their first degree, owing to the fact that having a non-legal background may impinge on their views about international law.

The total number of students at USP, PCU, MPU and GVF varies greatly. USP, a tuition-free public university, admits 460 applicants annually by means of a public entrance examination known as FUVEST. PCU, MPU and GVF, albeit private, have their own versions of this test, for respectively 550, 1,080 and 60 admissions every year. Here we decided to extract a larger sample from USP, which is the main target of our enquiry. Since none of these four had a policy of separating students according to any criterion, we randomly selected four 60-student classes (240 students in total) from each of the second and third years at USP, three 50 -student classes (150 in total) from each of the same years at PCU, four 50-student classes (200 in total) in the same pattern at MPU, and all first- and third-year students at GVF (in the latter case, by virtue of its small size, we were able to administer the ques- 
tionnaire to the whole student body).

This paper has a quantitative and a qualitative strand. The questionnaire contains closed (objective, survey-style) questions - aimed at gathering personal details of the respondents, as well as quantifiable measures for a number of parameters related to the main points - and open (subjective) ones. For the first group, we relied on simple linear regression to determine the correlation between each of the variables. For the second one, we used discourse analysis, as will be explained below (section 3.1).

A final observation: although the answers in the questionnaires are in Portuguese, we have taken the liberty of freely translating them into English as required. In any case, we have always indicated the reference number for each response, so that it can be located in the original database. The code has three components, as follows: U.3-XII.1. The first letter indicates the university ("U" for USP, "P" for PCU, "M" for MPU and "G" for GVF), the second letter-number combination designates the year and class, and the last number is the response number within that class. Due to space constraints, direct citations of primary material have been used sparsely as heuristic devices to support our argument. In any case, the responses are transcribed in their full content so as to disclose the source material from which we construed our reading.

\subsection{Research progression and potential biases}

Fieldwork was conducted over a period of two months in August and September of 2014. One of the obstacles encountered was securing official permission to visit classrooms and administer the questionnaires, both from the administration of the four universities and each professor. The first task was accomplished through a visit to the dean of each school; the second, by writing individual e-mails containing a letter of introduction and a synthesis of the research project. The visits took place during international law or related classes wherever possible - only when international law classes were not on offer were other courses chosen. Admittedly, this is a latent bias factor in the responses, but not a fatal one; for the purposes of this research the decision was made not to factor the subject of each class in, as precise instructions to the effect that answers should be as objective as possible and guarantees of absolute anonymity were given before the distribution of the questionnaires. The questionnaires were handed out either before or after lectures, according to the wishes of each lecturer.

An empirical study of perceptions and attitudes is always subject to methodological criticism, the biggest of which concerns whether students were sincere in their responses. Be that as it may, our hope is to illuminate in part the discussion about international law teaching in Brazil.

\section{Irrelevant verbiage? Myths about international law among law students}

\subsection{The myth of international relations}

We present the empirical findings in the next two sections, starting with the first part of this project, concerning students' perceptions and attitudes about international law as a branch of law.

The theoretical framework used in this section is based on the idea of myth. The overarching assumption is that the world is built by language. Words do not just reflect reality; they construct it (Chandler 2007:10). Our access to the world is mediated by language; the subject and object communicate only by means of representations in a mutually constitutive dialectical manner. In this sense, the world (or, to be more precise, what one perceives the world to be) is made up of semiological systems constituted of signs (Chandler 2007:10). Epistemologically, a sign is anything that communicates information (meaning) that is distinct from the sign itself; it stands for something other than itself. In linguistics, the sign is a dyadic model composed of a concept (the signified) and a sound pattern (the signifier), both of which are psychological (non-material) phenomena (Saussure 1995:97). The sign is the whole that results from the association of the signifier with the signified. The myth, like language, is a semiological system, but a secondary one. The sign of the primary system becomes the signifier of the second, and a new signified is attributed to it ${ }^{6}$ (Barthes 1970:224).

6 An illustration is given by Barthes: imagine you are a student of 
This secondary process of interpretation and meaning-attribution happens at all levels of discourse, including within the academic field of IR. For example, IR schools ${ }^{7}$ are, in this sense, nothing but myths about the functioning of international relations - ideological lenses through which we build and see the world. "An IR myth is an apparent truth, usually expressed in slogan form, that an IR theory relies upon to in order to appear to be true" (Weber 2010:2). It includes core concepts of IR, such as anarchy, state, power, market, and egoism, among others. Through these fragments, we can retrace the intellectual steps that led to the worldview (the myth) expressed in each response.

Perhaps the most apposite remark here is that international law, like semiotic systems, works like a mesh: its words are the open spaces between the wires, being completely devoid of meaning in and of themselves (vacuum) and only making sense when juxtaposed with other words (Kennedy 2002:195). The principal idea behind this project is that international law-making is not the sole province of the movers and shakers of high diplomacy; it may be the product of the interactions of people engaged in discourse about the good and bad in the international arena, projected as collective consciousness, and thus socially constructed (Focarelli 2012:34) - or perhaps "inter-subjective". This is the driving force of this research: to unveil the politics of international law by clarifying how it is thought and spoken of. And, in its quality as a parole, a speech-act, the myth is a story, a narrative about the world.

In this article, we make a more sociological use of

Latin grammar, and you come across the sentence "quia ego nominor leo" ("because I am named Lion") from the fables of Aesop. At once your mind faces an ambiguity: the phrase is not trying to convey that the message's decoder (the reader, yourself) is named Lion; nor is it the case that someone is actually called Lion. These are not the true meanings of the sentence - although they could be said to be the meanings of the primary sign. But at this moment, context and ideology intervene and cover the first sign in a new signified, namely that "this phrase is an example of grammar" (Barthes 1970:227).

7 Despite our using IR theory vocabulary, no attempt was made to fit discourses in the mould of any of these schools of thought - our approach is necessarily inductive. Any use of the terms "realist", "liberal", "constructivist" and others serves as an instructive analogy only. As we point out below, we have reconceptualised some of the initial categories in accordance with the findings. the myth: while retaining the helpful epistemological background, the myth is equated with a representation (or image) that students have of international law. Sometimes the myths appeared already in the final form, by means of general statements about international law or international relations; sometimes, we needed to induce them from less abstract answers about concrete facts or events, and in this we sought to identify the hidden assumptions about international law and order that lie behind them. This is the secondary process of interpretation and meaning-attribution alluded to above: to understand the deeper content of each response, we should abstract away from the concrete in order to spot the additional layers of meaning that surround a given sentence.

In describing the myths, we employ methods of discourse analysis. There are no strict rules for this methodology; it is data-driven, which means that categories and approaches are determined by the data. Tonkiss (2012:413) singles out some pointers that will be considered: (1) identifying key themes and arguments (what ideas and representations cluster around key themes?); (2) looking for association and variation (what associations are established between different actors and ideas?); and (3) attending to emphases and silences (what is in the foreground and what is left unsaid?). Each of these pointers will be taken into consideration throughout the text, but will not be specifically mentioned as such, since the analysis is holistic rather than informed by any exhaustive set of criteria. Also, discourse analysis does not require an account of every line of material; as said, we shall be selective when utilising the data gathered (Tonkiss 2012:412).

\subsection{International law and its relevance in international relations}

This is the first anchor of our research, where we tackle the first research question. We seek to identify which myths about international law prevail among law students at the universities selected for the fieldwork, and for this our initial hypothesis was that a "realist" myth predominated.

Questions 5 ("On a scale of one (completely disagree) to five (completely agree), how much do you agree with the following statement: "in general, public interna- 
tional law is an important factor in international relations'?") and 10 ("Considering your answer to question 5, how do you understand the role of public international law in international relations?") were designed to fulfil this purpose. Question 5 assesses whether students believe that international law is, broadly speaking, an important factor in international relations, on a numerical scale of 1 to 5 , and Question 10 delves deeper into that answer by asking students to elaborate on the score.

\subsection{Redeeming international law?}

As a lead-in to the myth analysis, Table 1 presents the averages for Question 5, broken down by institution and divided into two sets: in the first column, partici- pants had just started their international law modules, whereas in the second, they had already filled their quota of the subject (i.e. second-year students for USP, PCU and MPU and first-year students for GVF in Group A and third-year students for all universities in Group B). This should allow us to infer whether there is a correlation between education and a change of opinion, or at least any extraordinary shift in the figures. The table also furnishes data on standard deviation for each group, so as to quantify the amount of dispersion of this set of data values (a low standard deviation indicating that the data points tend to be close to the mean, also known as the expected value, and a high standard deviation indicating that the data points are spread out over a wider range of values).

Table 1 - averages for Question 5, broken down by university and year

\begin{tabular}{|c|c|c|c|}
\hline & $\begin{array}{l}\text { GROUP A: mean } \\
\text { (number of respondents) } \\
\text { standard deviation }\end{array}$ & $\begin{array}{l}\text { GROUP B: mean } \\
\text { (number of respondents) } \\
\text { standard deviation }\end{array}$ & Total \\
\hline USP & $\begin{array}{l}3.2958362385(238) \\
0.950693444\end{array}$ & $\begin{array}{l}3.23715415(237) \\
1.07970225\end{array}$ & $\begin{array}{l}3.26649519425(475) \\
1.003725788\end{array}$ \\
\hline PCU & $\begin{array}{l}3.5365853655(143) \\
0.83437153\end{array}$ & $\begin{array}{l}3.380952381(130) \\
0.961512552\end{array}$ & $\begin{array}{l}3.45876887325(277) \\
0.878689628\end{array}$ \\
\hline MPU & $\begin{array}{l}3.326822491(216) \\
0.988397914\end{array}$ & $\begin{array}{l}3.56779661(195) \\
0.72180701\end{array}$ & $\begin{array}{l}3.4473095505(411) \\
0.921450544\end{array}$ \\
\hline GVF & $\begin{array}{l}3.403846154(53) \\
0.955061139\end{array}$ & $\begin{array}{l}3.348837209(44) \\
0.948274647\end{array}$ & $\begin{array}{l}3.3763416815(97) \\
0.947324871\end{array}$ \\
\hline Total & $\begin{array}{l}3.39077256225(650) \\
0.953693257\end{array}$ & $\begin{array}{l}3.3836850875(606) \\
0.982544785\end{array}$ & $\begin{array}{l}3.387228824875(1.256) \\
0.963975859\end{array}$ \\
\hline $\begin{array}{l}\text { GROUP A: students at the beginning of their } \\
\text { international law studies } \\
\text { GROUP B: students with all international law } \\
\text { courses completed }\end{array}$ & & & \\
\hline
\end{tabular}

Surprisingly, these numbers contradict the initial expectation that the standard view was against the idea of international law having any force (effectiveness) in international relations. If anything, the average student was quite favourable to this way of thinking: even if one takes into account standard deviations, the balance clearly seems to be tilting towards the positive end. In addition, no major gaps exist between the universities: all means are within the range of three to four. This even applies to GVF, which, as was seen in the previous section, adopts a teaching methodology different from that of the other universities.
The most outstanding feature of the table, however, is that, with one exception (MPU), perceptions about the role of international law worsened after students had taken the course. This is tantamount to saying that, at a minimum, international law education as it stands at those universities does not have a significant impact on students' worldviews in respect of ascribing force to international law (or, worse yet, it may be so detached from their realities that it comes across as futile). This fact is congruous with the findings concerning the myths, as will be seen below. And once again, no discrepancy exists in relation to GVF, in spite of their distinct teaching methodology. 
It is important to note, however, that the fact that GVF follows the lead of other schools does not rebut the argument in favour of an interdisciplinary education. It is simply that, in general, students are not as sceptical about international law's role as one would think, and therefore having classes about international law does not significantly affect this rather liberal view.

\subsection{Fourth myths about international law and international relations}

The responses to Question 10 put flesh on the numbers above. They revolve around four myths, which we call sovereigntist-regulatory, materialist-determinist, value-proselytist, and complex-globalist; these can be inferred from the nature of the stated or - even more importantly - unstated assumptions about international law and international relations in each of the answers, as explained above. Of course, none of these four myths are mutually exclusive: quite on the contrary, there is strong interplay among them. Nevertheless, for the sake of clarity, we shall go over each one in turn. And, as will be seen, their occurrence was evenly distributed among all universities and classes, there being no notable divergences in quantitative terms.

\subsection{The sovereigntist-regulatory myth}

By an overwhelming margin, this was the most common myth across all groups. It is a narrative about rules and constraints, in which international law plays the role of mediator in the relations between equal sovereign states. Indeed, international law is the very shield of sovereignty that brings about predictability and stability to an otherwise chaotic world. The motto here is order and, even more so, efficiency: there is a hidden ideological standard to judge whether relations are being conducted ideally or not.

"The role of public international law is central in the regulation and organisation of international relations, through the imposition of limits and principles to be observed" (U.3-XI.32). As a tool for regulation, international law "has an important role in clarifying what is expected of countries in their international relations and in settling disputes that may arise" (U.3-XII.2). In terms of politics, there is also an unmistakable liberal and rationalist flavour to this myth: it speaks of peace (as the absence of armed conflict), trade, and human rights, as well as of equality. International law "governs the relations among countries and constrains their conduct in relation to human rights, war, trade etc." (U.3-XI.30). Fostering these objectives is what is meant when this one student says that "international law is of the utmost importance for the development of international relations in an efficient manner" (M.3C.17). International relations are the relations between equal parties, all of which are nation-states.

A further ramification of this debate concerns the nature of the relations to be regulated: are "state interests" conflictual or harmonious? Here we can see the echo of Anzilotti's distinction between contracts between states ("contrats entre états"), in which the declarations of will by the parties are substantively different but converge on a common end, and collective acts, whose purpose is the satisfaction of common interests or the exercise of shared powers (Anzilotti 1929:352). The first kind is illustrated by U.3XI.17: "Public international law has an important role in international relations to regulate the relations between states and to prevent the pursuit of their own interests from going against the maintenance of peace and human rights, for example". On the other side of the spectrum lies M.3D.17: "Public international law is of the foremost relevance for the regulation of relations between states. With a strong and enforceable international law, peoples will tend to become more harmonious and focus on aims for the common good of society. With a strong international law, we will consider not only peoples individually, but the whole of humanity as an entire body". As can be seen, the nature of the regulation in this myth is disputed.

This myth's ubiquity is undoubtedly food for thought. Brazilian law schools, and especially those under examination, are the very habitat of legal dogmatics. Unger (2005:18) postulates that legal education, in Brazil and worldwide, currently navigates between two formalisms: the "old", founded upon the study of legal ideas as a system that could be analysed by deduction and the exposition of positive law as enacted by legislators and judges, and the "new", according to which norms should be analysed and interpreted with a view to subjacent values, interests, and public policies. Perhaps in this myth we can discern the 
silhouette of the "old" formalism, ever preoccupied with strict regulation, as if society (both domestic and international) were made up of rational and selfish individuals in the market.

\subsection{The materialist-determinist myth}

The second most common was the materialist-determinist myth. As the name implies, this is an umbrella category that incorporates ways of thinking affiliated with a materialist philosophy, in the sense that there pervades an inexorable physicalism (the world is wholly matter) and determinism (the empire of necessity); thus, it congregates both realist and Marxist-inspired takes on international law, which share several epistemological assumptions. Thus, "from a radical materialist perspective, one can dismiss the realist 'apology of brute force' and 'colossal moral insensitivity' while learning from (and attempting to ground in nuanced historical context) [realism's] unsentimental sense of the political realities underlying international law" (Miéville 2005:155). This myth can thus flourish on both the left and the right sides of the political spectrum.

This myth tells of struggles for domination, and of how law is the handmaid of power. The protagonists are states (be it as standalone actors or as a mirror of global capitalism), ever in competition for military and economic influence; the scenario, a free-for-all, ruthless battlefield where the only reliable law is that of the jungle. But this is a story that leaves no place for international law as anything other than an epiphenomenon or a tool for oppression. In brief, it is a dystopia in which the leviathans live out their eternal days in permanent insecurity and fear for their own survival.

The most recurring theme, and probably the very foundation of this myth, is the neat polarity between law and politics, which are held to belong to different dimensions. Law is seen either as empty speech (law is not politics: it simply cannot triumph over the force of the latter) or as a product of politics (both are genetically inextricable, and the legal is subjugated to the political, but one cannot be ontologically mistaken for the other). In sum, law is seen as a metaphysical body of rules that relates to politics, but cannot be confounded with it. This is in contrast to a sociological understanding, which would underline the continuum that blends law, culture and politics as a single reality.

For instance, one student wrote that "the cultural and economic factor overcomes international norms, that is, countries in most cases choose the avenue that best fits its cultural values and economic advantages rather than international norms" (M.3D.10). Another said that "international relations do not only involve legal knowledge, but also political and economic influence; therefore, public international law is important, but should not be the only means of resolving international matters" (U.3-XIV.5). These two examples show a sharp boundary between "cultural values", "economic advantages" and "political and economic influence" on one side and "international norms" and "public international law" on the other. And insofar this divide exists in international relations, which "are based in the power of the state, [...] there is a superposition of political interests over public international law" (P.3M.55).

The next image constantly invoked is that of power, conceived as military prowess and economic might: "Law is power. Public international law is power. Behind the legal norm there is no enlightened reason or immutable and eternal justice, but force. For that reason, each country will only abide by the norms if they are convenient and if it has political or economic power" (U.2-XXI/XXII.28). These are the true determining factors of international relations before which international law is either weak, or merely an extension of these factors. The first group comprises "realists" who recognise an independent normative gravity in international law, in spite of problems of enforcement: international law is not purely descriptive, but is also prescriptive. In the second group, law is stripped of its normativity, and becomes apologetic and subservient to power. It includes a second current of "realism" that portrays international law as a prolongation of the joust for supremacy between great powers, and another strand that employs Marxist vocabulary such as the dichotomy between "centre" and "periphery", "imperialism", and "dominance”.

One example of the first group is G.1-S.16: "Public international law is important to a certain extent for consensus and settlement of disputes in an interna- 
tional ambit, but I believe it is also still limited and powerless when it comes to the effectiveness of the enforcement of its norms. Economic and military dominance are certainly a central factor internationally". Here the emphasis on economic and military elements, as well as their predominance over law, is expressly stated. An illustration of the second group is M.2C.12: "International relations are unbalanced power relations, and often peripheral countries are pressured by the rules of international law, while central countries violate them". Awareness of the relative position of Brazil thus appears to be an important part of discourse about international law here.

The final element of this myth is the prominence of the state as the main actor in international relations; indeed, the international sphere seems to be defined by the presence of a multiplicity of sovereigns. These are self-interested monolithic entities, and, as in realist theories, there is no reflection about how these interests originate. The idea of interest, then, assumes a transcendental character and is naturalised: "I believe that international relations happen by means of state interests and the dynamics of global markets. Public international law cannot face those dynamics, and has a merely recommendatory role" (U.2-XIII/ XIV.53). This answer is particularly representative because, in addition to mentioning the abstract notion of "state interest", it also incarnates the spirit of causality and inevitability that impregnates the myth: the (material) market forces are unstoppable, and they determine how the world works.

The contours of this myth sit well with the Brazilian law school environment. International law is one of the last subjects to be introduced to students, normally at some point during their second year (the only exception being GVF, which has an introductory course in the first semester, as mentioned above). One wonders whether this encourages a view of international law based exclusively on a comparison with its municipal counterpart: the focus on sanctions leads to an appeal to power and violence (whose monopoly belongs to the state), and in the absence of which international law cannot be deemed to be "law".

\subsection{The value-proselytist myth}

This is a tale about a preaching international law. Here, international law becomes the holy text of universalization, speaking the lexicon of common values. The state, formerly the almighty apex of international relations, fades away and is replaced with the individual, who takes centre stage as the very raison d'être of the international legal regime, and an ethical parameter according to which one can judge states' behaviour comes into sight: human rights as secular scripture. International law is transformed into a yardstick of legitimacy for government actions.

A paradigmatic example of this myth is U.3-XII.31: "Public international law is important for our country because it helps the domestic advancement of Western values that our country claims to support. For instance, it was by international means that Maria da Penha obtained justice and had her rights respected". Proselytism is pinpointed as occidental, and meticulous reference is made to a headline-making case at the Inter-American Commission of Human Rights. In the same vein, M.3D.3 seems to equate international law with human rights: "Public international law is a field of law that is extremely important for the regulation and implementation of Human Rights, which are guarantees that should be extended to the population of the world. The Law as a whole is only fair if such principles are applied". The idea of expansion lurks behind the universalism of this discourse.

This myth cannot hide its Kantian disposition, and thus its position alongside the liberals at the supposed centre of the political spectrum. Human rights are the tune for the march towards the civitas gentium, or at least a phoedus pacificum - a voluntary, non-coercive federation, with a whiff of a hard-headed understanding of human nature (Perreau-Saussine 2010:54): humans are unjust, but at the same time they are free and may act in accordance with maxims that will lead to their giving up their savage (lawless) freedom, accommodate themselves to public coercive laws, and so form an (always growing) state of nations (civitas gentium) that would finally encompass all the nations of the earth.

To borrow from Unger's (2005) terminology, this approaches the "new" formalism in legal education: (international) law is not simply about impartial regulation, but militant activism advancing a set of values. 
From this angle, law is not neutral, and it is the duty of the jurist to put it to use for the common good. It is the denial of legal impartiality, and as such, together with the "old" formalism of the sovereigntist-regulatory myth, embodies one of the poles between which legal education fluctuates.

\subsection{The complex-globalist myth}

Lastly, the complex-globalist myth is about an increasingly interdependent and interconnected world. It is a palpably melancholic requiem that longs for a lost world of nations and is bewildered by the Brave New World of globalisation. Looking back on the past, in recent years the development of means of communication and transport has irrevocably changed the way international relations work: "Globalisation and the constant process of shortening of distances cause relations between subjects of international law to become unavoidable" (U.3-XI.11). Therefore, "Public international law has become crucial today, due to the deeper connections between countries that creates new relations (be they peaceful or not) that law must regulate with rules and principles" (M.2E.18). This is also associated with the fact that "The expansion of public international law demonstrates a phenomenon of dissolution of both the state and its tutelage. There is a clear tendency of blurring of frontiers in favour of migratory and informational fluxes" (U.3-XII.16).

E pluribus unum: this myth pledges a rainbow of cultures, law and interests in an implacably more monochromatic world. Its maxim is coordination: existence is irremediably diverse, but since globalisation has done away with geographical and mental barriers, it is imperative that the relationship between the units be harmonised, while preserving heterogeneity. It is a cousin to normative pluralism, "the idea that behaviour can be evaluated from the perspectives of a variety of normative orders or normative control systems and thus, importantly, can also be justified from a variety of such perspectives" (Klabbers and Piiparinen 2013:14). This shade of the complex-globalist myth is, in a sense, the alter ego of the value-proselytist one: globalisation not as a stairway to federalism, but as the high road to perennial (legal) pluralism (Koskenniemi 2007:20), understood here as the geographically segregated coexistence of several legal orders within the same geo-political space. This is conspicuous in U.2-XXI/XXII.17: "The role of Public International Law is to provide unity and promote debate leading to a harmonisation of interests within a context of diversity of interacting countries in the process of globalisation". Hence, we have here the negation of Kant's civitas gentium, understood as the universal state.

It is interesting that while domestic legal pluralism is looked upon as a project of the left, international legal pluralism can be taken as leaning to the (realist) right. Contrary to the (left-wing) idealism of Lauterpacht (1933) that aims at universal law and government, pluralism appears to resign itself to an ineluctable (and conflictual) Babel of nations.

\subsection{Prevalence of each myth relative to the others}

The landscape would not complete without a quantitative look at the prevalence of each myth within Groups A and B. Table II shows the percentage of responses in each group that contained elements of each myth, in relation to the group aggregate. It also supplies data on totals.

Table 2 - percentages of responses to Question 10 by myth, broken down by year

\begin{tabular}{|l|l|l|l|}
\hline & $\begin{array}{l}\text { GROUP A: group } \% \text { (number of } \\
\text { answers) }\end{array}$ & $\begin{array}{l}\text { GROUP B: group \% (number of } \\
\text { answers) }\end{array}$ & Total \\
\hline Sovereigntist-regulatory & $67.9 \%(442)$ & $52.9 \%(314)$ & $60.8 \%(756)$ \\
\hline Materialist-determinist & $2 \%(121)$ & $22.8 \%(135)$ & $20.6 \%(256)$ \\
\hline Value-proselytist & $4.3 \%(28)$ & $10.6 \%(63)$ & $7.3 \%(91)$ \\
\hline Complex-globalist & $8.4 \%(55)$ & $9.4 \%(56)$ & $8.9 \%(111)$ \\
\hline Total & $94.2 \%(613)$ & $94.5 \%(560)$ & $94.3 \%(1.173)$ \\
\hline TOTAL OF RESPONSES TO QUESTION 10: $1,244($ GROUP A: $651 /$ GROUP B: 593$)$ & \\
\hline
\end{tabular}


As in Table 1, the most striking change is the increase in the percentage of some groups to the detriment of another. In this case, comparing the first and the second columns, the sovereigntist-regulatory myth gives way to the materialist-determinist, value-proselytist and complex-globalist myths. We had put forth the hypothesis that overall faith in international law's effectiveness declined as students progressed in their studies, and these numbers partly corroborate that thesis. The concept of international law as regulation between sovereigns loses its centrality, and this is matched by a corresponding rise of $4.2 \%$ in the proportion of the materialist-determinist myth.

But while students have indeed become more "realist" or "pragmatic", they have also converted en masse to the value-proselytist myth: that is, they began to equate international law with the spread of a certain set of values, the most basic of which is human rights. But in so doing, international law loses its teeth as law conceived as coercion: it becomes a moral barometer by which to pass judgment on a given state of affairs. As such, it is undistinguishable from political philosophy, situated in the realm of the normative, where everything is imaginable. Or, to loan from Koskenniemi (2005), their perception of international law oscillates towards utopianism, jettisoning stronger claims to follow the actual practice of international relations. Association of international law with human rights, in particular, distances it from a ius potestas vision of law - one that entails law as an factor external to the agent that is to be enforced - for the benefit of a ius auctoritas view - or law as having an immanent authority without the need for a policeman.

\subsection{International law and national interests} One of the chief tenets shared by all rationalist IR theories is that when confronted with a norm that seems to go against its interests, a state will always choose non-compliance over sacrificing potential benefits; international law enforcement only goes unhampered when legal precepts and perceived interests are one and the same. This is due to the supposed selfishness of states that inhere in their nature or in the structure under which they behave, and is explicit in the writings of scholars such as Mearsheimer (1995:9), Keohane (1982:327), and Posner (Posner and Sykes 20122013:1027). We take this in opposition to a "moral" perspective that would associate law with justice and regard a violation as an immoral act.

The purpose of Question 6 ("Which of the statements below best reflects your opinion? A. Brazil should always comply with public international law. It is wrong to violate public international law, just as it is wrong to violate Brazilian laws; B. If it is not in Brazil's interests, Brazil should not comply with public international law.") is to gauge students' attitudes in terms of two propositions: the first (" $A$ ") states that it is wrong to breach international law, and the second ("B") says that Brazil should not abide by international law when a conflict of interest emerges. It is true that these alternatives do not exhaust the full breadth of opinions in this area, but this dichotomy is convenient here. Table 3 details the results.

Table 3 - percentages of responses to Question 6, broken down by university and year

\begin{tabular}{|l|l|l|l|}
\hline & $\begin{array}{l}\text { GROUP A } \\
\text { A\%, B } \% \\
\text { (number of respondents) }\end{array}$ & $\begin{array}{l}\text { GROUP B } \\
\text { A\%, B\% } \\
\text { (number of respondents) }\end{array}$ & Total \\
\hline USP & $61.1 \%(147), 38.9 \%(93)$ & $74.2 \%(178), 25.8 \%(62)$ & $67.7 \%(325), 32.3 \%(155)$ \\
\hline PCU & $58.1 \%(82), 41.9 \%(59)$ & $77.9 \%(113), 22.1 \%(32)$ & $68.2 \%(195), 31.8 \%(91)$ \\
\hline MPU & $71.9 \%(141), 28.1 \%(55)$ & $63.1 \%(123), 36.9 \%(72)$ & $67.5 \%(264), 32.5 \%(127)$ \\
\hline GVF & $78.8 \%(41), 21.2 \%(11)$ & $51.2 \%(22), 48.8 \%(21)$ & $66.3 \%(63), 33.6 \%(32)$ \\
\hline Total & $65.3 \%(411), 34.7 \%(218)$ & $70 \%(436), 30 \%(187)$ & $67.5 \%(847), 32.5 \%(405)$ \\
\hline
\end{tabular}

The students mostly opted for Statement "A", with perhaps the only odd case being GVF's Group B, which had a narrow majority that may be attributed to varia- tions in class attendance. Students do, in general, take the view that international law should be followed in spite of national interests; we can possibly detect a 
vague notion of public order in these figures, which are congruent with the results for Question 5. However, a cleavage leaps to the eye: in two of the universities (USP and PCU), the proportion of " $\mathrm{A}$ " responses increased in Group B, whereas in the other two (MPU and GVF), it decreased. In total, there was an increase, but this is due to sample size variation. On that account, we refrain from making conclusions, except for pointing out that differences in teaching methods and content in international law classes are worth looking into in the future.

So, how do we take stock of the two ostensibly contradictory observations in this section, i.e., a duopoly of regulatory and materialist myths and great normative deference for international law? One possible answer is that the mythology here is descriptive, while the perceptions in Question 6 are normative. Therefore, for each of the myths, the guidelines for action in the world - how should one act before a given set of circumstances - are at variance. In other words, their ethics are distinct. The ethics of the sovereigntistregulatory myth are those of liberalism: rules exist for the regulation of relations between individuals in an orderly fashion, and respect for them is paramount for the functioning of the market, even if they bring about unwelcome outcomes in the short term. That is, obedience is the key to the survival of the system itself, and self-sacrifice is thus warranted. As for the materialist-determinist myth, its ethics are those of rebellion: devoted subjection to international normativity, whose violation is morally condemnable, even in face of the dire reality of international relations. Here the mood is that of swimming against the tide, urging loyal compliance with international law, perhaps in hopes of systemic change through individual action, perhaps in order to keep the moral high ground. In either case, the legitimacy of international law is unquestionable.

\subsection{Conclusion: thriving in diversity?}

This section has shattered the idea that realism prevails as a mindset among law students. Instead, we have seen four myths emerge - and they are reflective of the broader political spectrum. Some of them wear the deceptive mask of descriptiveness and objectivity, whereas others openly flaunt their normative credentials. Perhaps unsurprisingly, law students express their views about and aspirations for international law through their political lenses, be they left- or right-leaning.

Another point relates to how much of a role international law plays in students' minds. Perhaps here we can bring in Santo's (1988) work on legal pluralism (conceived not, as above, as geographically segregated coexistence, but as a geographical coincidence that chronologically alternates between different scalebased legal realities) using the map as a metaphor, to say that "world law" (which includes international law) is a small-scale legality, meaning that legal reality that regulates from a more general, macro perspective, which is distant from the medium-range, state-lawbased scale of municipal lawyers (Santos 1988:164165). Although law students are aware of the existence of international law and its effects on legally regulated situations, and in practice is brewed together with smaller and larger scale legalities in a juridical melting pot (or, in Santo's terminology, inter-legality) (Santos 1988:164). For a continentally-sized country such as Brazil, where even national federal may seem smallscale at times and where local laws are central to the legal scene, world law shrinks to even further diminutive proportions, and its moralistic-sounding content (Santos 1988:164) may dim its appearance as "law".

The main question is, however, what to teach when there is no consensus on the place of international law in the world. International law is a technical discipline, and therefore rules and judgments will always be a part of game. But since a theoretical introduction is always given in any introductory course, perhaps the soundest approach is to briefly introduce different schools of thought on international law so as to allow the student to choose his or her own lenses through which to understand the world of international relations and international law, and to challenge their pre-conceptions about the discipline. It is counterproductive and even damaging to evade empirical questions of IR, and international law classes should face up to them. This necessitates, however, an overhaul of the current methodology in order to suit the wishes of students and the demands of an interdisciplinary curriculum. This will be dealt with in the next section, in which we present the data on perceptions and attitudes towards international law as a law school course and as a professional asset. 


\section{4}

\section{Unnecessary hurdle? International law in the legal curriculum and profession}

\subsection{Professional ambitions among law students}

As a prelude to this section, in which we analyse the impact of international law classes on students' perceptions of the discipline and, by extension, perceptions about international law as a component of legal education, it is informative to sift through the responses collected for Question 4 ("Do your career plans include any of the options below? If not, please leave it blank. a. Public-sector legal professions; b. Private-sector legal professions; c. Diplomacy or international organisations"). In Table 4, which summarises the data according to university and year, public-sector careers are represented by the first group of figures ("a"), private-sector careers by the second group of numbers ("b"), and international careers are represented by the third group of figures ("c"). The percentages are in relation to the total number of responses, and respondents were allowed choose more than one option.

Table 4 - percentages of responses to Question 4, broken down by university and year

\begin{tabular}{|c|c|c|c|}
\hline & $\begin{array}{l}\text { GROUP A } \\
a \%, b \%, c \% \\
\text { (number of responses) } \\
\text { total number of responses }\end{array}$ & $\begin{array}{l}\text { GROUP B } \\
\text { a\%, b\%, c\% } \\
\text { (number of responses) } \\
\text { total number of responses }\end{array}$ & Total \\
\hline USP & $\begin{array}{l}70.3 \%(156), 43.2 \%(96), 18.9 \%(42) \\
222 \text { responses }\end{array}$ & $\begin{array}{l}65.8 \%(148), 44 \%(99), 12 \%(27) \\
225 \text { responses }\end{array}$ & $\begin{array}{l}68 \%(304), 43.6 \%(195), 15.4 \%(69) \\
447 \text { responses }\end{array}$ \\
\hline PCU & $\begin{array}{l}69.9 \%(102), 49.3 \%(72), 24 \%(35) \\
146 \text { responses }\end{array}$ & $\begin{array}{l}66, . \%(96), 37.2 \%(54), 20.7 \%(30) \\
145 \text { responses }\end{array}$ & $\begin{array}{l}68 \%(198), 43.3 \%(126), 22.3 \%(65) \\
291 \text { responses }\end{array}$ \\
\hline MPU & $\begin{array}{l}68.2 \%(133), 42.6 \%(83), 15.9 \%(31) \\
195 \text { responses }\end{array}$ & $\begin{array}{l}65.3 \%(126), 36.8 \%(71), 7.8 \%(15) \\
193 \text { responses }\end{array}$ & $\begin{array}{l}66.7 \%(259), 39.7 \%(154), 11.8 \%(46) \\
388 \text { responses }\end{array}$ \\
\hline GFV & $\begin{array}{l}28.4 \%(15), 84.6 \%(44), 26.9 \%(14) \\
52 \text { responses }\end{array}$ & $\begin{array}{l}26.8 \%(11), 87.8 \%(36), 24.4 \%(10) \\
41 \text { responses }\end{array}$ & $\begin{array}{l}27.9 \%(26), 86 \%(80), 25.8 \%(24) \\
93 \text { responses }\end{array}$ \\
\hline Total & $\begin{array}{l}66 \%(406), 48 \%(295), 19.8 \%(122) \\
615 \text { responses }\end{array}$ & $\begin{array}{l}63.1 \%(381), 43 \%(260), 13.6 \%(82) \\
604 \text { responses }\end{array}$ & $\begin{array}{l}64.6 \%(787), 45.5 \%(555), 16.7 \%(204) \\
1.219 \text { responses }\end{array}$ \\
\hline
\end{tabular}

The first fact to be noted is that international careers are a minority taste across all universities and groups; indeed, the highest percentage was $26.9 \%$ for GVF's Group A, or a little more than a quarter of respondents. Two of the universities - PCU and GVF - seem to have a cohort with a greater propensity for foreign affairs, but as will be seen below, even in those cases the numbers dwindle when comparing Groups A and B.

The same pattern observed in the previous tables is replicated here: international law-related choices are much less popular among members of Group B than Group A. If anything, courses in international law have dissuaded students from professions in the field. The differences are staggering: at USP, whereas $18.9 \%$ of respondents expressed an interest in diplomatic or international civil service careers before studying international law, only $12 \%$ did so after having had the two mandatory semesters - a plunge of almost $7 \%$. At PCU, the respective numbers are $24 \%$ and $20.7 \%$, a plummet of 3.3\%; at MPU, $15.9 \%$ and $7.8 \%$, a dramatic drop of $8.1 \%$; and finally, at GVF, $26.9 \%$ and $24.4 \%$, a softer contraction of $2.5 \%$. The big winners were unequivocally private practice jobs - that is, mostly lawyers in law firms. There seems to have been a massive shift away from international careers to private ones, except for GVF, where this predilection was patent from the beginning.

Evidently, a host of factors can be marshalled in order to account for this deflection. Perhaps acquaintance with subjects such as commercial law, and their related career options, dents students' commitment to international careers? Still, it is worth considering the extent to which international law classes may have played a role in this debacle, or at least if they could 
have made it less ignominious. One can conjecture that more stimulating courses could have offset some of these statistical losses, and one option would be to tie the content of the classes up with up-to-date professional practice in both traditional domestic legal careers and the practice of Brazilian diplomacy and international organisations. As will be seen below, one of the major dissatisfactions among students was the dearth of case studies and the academicism of classes, which, in contrast to other subjects at law school, are more practical and of immediate application.

4.2 International law as a law school course The second facet of this research enquires into stu- dents' perceptions about the function of international law as a discipline in the legal curriculum. We will scrutinise the hypothesis that law students do not consider international law to be an integral part of legal education. Questions 7 ("Do you think public international law should be a mandatory subject in the law curriculum? a. Yes, with more class hours than today (45 hours); $b$. Yes, with the same number of class hours as today (45 hours); c. Yes, with fewer class hours than today (45 hours); $d$. No") and 8 ("If public international law were an optional module, would you choose to take it? a. Yes; b. No") deal with this issue, the latter being a continuation of the former. Tables 5 and 6 present the results.

Table 5 - percentages of responses to Question 7, broken down by university and year

\begin{tabular}{|l|l|l|l|}
\hline & $\begin{array}{l}\text { GROUP A } \\
\text { a } \%, \mathrm{~b} \%, \mathrm{c} \%, \mathrm{~d} \% \\
\text { (number of respondents) }\end{array}$ & $\begin{array}{l}\text { GROUP B } \\
\text { a } \%, \mathrm{~b} \%, \mathrm{c} \%, \mathrm{~d} \% \\
\text { (number of respondents) }\end{array}$ & Total \\
\hline USP & $\begin{array}{l}16.5 \%(35), 66.5 \%(141), 17 \%(36), 0 \% \\
(0)\end{array}$ & $\begin{array}{l}13.9 \%(33), 58.8 \%(140), 27,3 \%(65), \\
0 \%(0)\end{array}$ & $\begin{array}{l}15.1 \%(68), 62.4 \%(281), 22.5 \%(101), \\
0 \%(0)\end{array}$ \\
\hline PCU & $\begin{array}{l}21.6 \%(32), 70.1 \%(105), 8.3 \%(11), \\
0 \%(0)\end{array}$ & $\begin{array}{l}16.1 \%(16), 76.8 \%(76), 7.1 \%(7), 0 \%(0) \\
19.4 \%(48), 73.3 \%(181), 7.3 \%(18), \\
0 \%(0)\end{array}$ \\
\hline MPU & $\begin{array}{l}24.1 \%(46), 62.8 \%(120), 13.1 \%(25), \\
0 \%(0)\end{array}$ & $38 \%(76), 58.5 \%(117), 3.5 \%(7), 0 \%(0)$ & $\begin{array}{l}31.2 \%(122), 60.6 \%(237), 8.2 \%(32), \\
0 \%(0)\end{array}$ \\
\hline GVF & $30 \%(18), 68.3 \%(41), 1.7 \%(1), 0 \%(0)$ & $21.7 \%(13), 71.6 \%(43), 6.7 \%(4), 0 \%(0)$ & $25.8 \%(31), 70 \%(84), 4.2 \%(5), 0 \%(0)$ \\
\hline Total & $\begin{array}{l}21.4 \%(131), 66.6 \%(407), 12 \%(73), \\
0 \%(0)\end{array}$ & $\begin{array}{l}23.1 \%(138), 63 \%(376), 13.9 \%(83), \\
0 \%(0)\end{array}$ & $\begin{array}{l}22.3 \%(269), 64.8 \%(783), 12.9 \%(156), \\
0 \%(0)\end{array}$ \\
\hline
\end{tabular}

Table 6 - percentages of responses to Question 8, broken down by university and year

\begin{tabular}{|l|l|l|l|}
\hline & $\begin{array}{l}\text { GROUP A } \\
\text { Yes\%, No\% } \\
\text { (number of respondents) }\end{array}$ & $\begin{array}{l}\text { GROUP B } \\
\text { Yes\%, No\% } \\
\text { (number of respondents) }\end{array}$ & Total \\
\hline USP & $89.4 \%(212), 10.6 \%(25)$ & $79.8 \%(190), 20.2 \%(48)$ & $84.6 \%(402), 15.4 \%(73)$ \\
\hline PCU & $86.5 \%(128), 13.5 \%(20)$ & $88.5 \%(131), 11.5 \%(17)$ & $87.5 \%(259), 12.5 \%(37)$ \\
\hline MPU & $80.9 \%(161), 19.1 \%(38)$ & $78 \%(156), 22 \%(44)$ & $79.4 \%(317), 20.6 \%(82)$ \\
\hline GVF & $95 \%(57), 5 \%(3)$ & $73.3 \%(44), 26.7 \%(16)$ & $84.1 \%(101), 15.9 \%(19)$ \\
\hline Total & $86.6 \%(558), 13.4 \%(86)$ & $80.6 \%(521), 19.4 \%(125)$ & $83.6 \%(1079), 16.4 \%(211)$ \\
\hline
\end{tabular}

Table 5 presents a few novelties: no respondent would elect to withdraw international law from the list of mandatory subjects for the law curriculum, and there is an overwhelming plurality across all groups in favour of maintaining the status quo relative to international law teaching, that is, a mandatory course load of 45 hours. A sizeable portion - in the range of one-fifth would desire more classes, a figure that is larger than that for students desiring fewer. But if in the aggregate the outlook is bright, a careful perusal reveals that, in conformity with Table 1, enthusiasm was undermined after students had finished their international 
law modules: between Groups A and B, in three of the universities, the percentage for "a" fell, as did that for "b" in two of these. In two cases, the number of "c" answers saw a substantial growth.

Table 6 paints a similar picture. Generally, respondents would choose to take international law if it were an elective. Nevertheless, there is a noticeable shift between Groups A and B (about 6\% overall, although again weight should be given to the difference in sample sizes), with the only exception being PCU. That is, students appear to be keener on the subject before they have actually been familiarised with it; once they have, this eagerness ebbs away. Once again, international law education does not seem to have affected students' perceptions positively.

\subsection{International law as a professional skill} Question 9 ("Considering your career aims, do regard public international law as relevant for your professional future? a. Yes; b. No") asks respondents to ponder whether they see the technical knowledge of international law to be employable in their current or future careers.

Table 7 - percentages of responses to Question 9, broken down by university and year

\begin{tabular}{|l|l|l|l|}
\hline & $\begin{array}{l}\text { GROUP A } \\
\text { Yes\%, No\% } \\
\text { (number of respondents) }\end{array}$ & $\begin{array}{l}\text { GROUP B } \\
\text { Yes\%, No\% } \\
\text { (number of respondents) }\end{array}$ & Total \\
\hline USP & $83.5 \%(193), 16.5 \%(38)$ & $75.2 \%(176), 24.8 \%(58)$ & $79.3 \%(369), 20.7 \%(96)$ \\
\hline PCU & $87.7 \%(128), 12.3 \%(18)$ & $87.9 \%(124), 12.1 \%(17)$ & $87.8 \%(252), 12.2 \%(35)$ \\
\hline MPU & $83.2 \%(163), 16.8 \%(33)$ & $78.5 \%(157), 21.5 \%(43)$ & $80.8 \%(320), 19.2 \%(76)$ \\
\hline GVF & $98.3 \%(59), 1.7 \%(1)$ & $83.3 \%(50), 16.7 \%(10)$ & $90.8 \%(109), 9.2 \%(11)$ \\
\hline Total & $85.8 \%(543), 14.2 \%(90)$ & $79.8 \%(507), 20.2 \%(128)$ & $82.8 \%(1050), 17.2 \%(218)$ \\
\hline
\end{tabular}

This part follows up on the previous one by investigating whether international law is seen as a useful professional skill for law students. Table 7 provides the compiled figures for Question 9.

It is clear that there is enormous endorsement for international law being a relevant professional skill, with more than $80 \%$ of respondents backing this proposition. Its position as part and parcel of a comprehensive legal education is by all means consolidated - not least because the Brazilian Bar Association (2009) requires international law in the form of a dozen questions in its bar exam,. Nonetheless, as elsewhere, there is an appreciable reduction when one moves from Group A to B. Students begin as curious learners of a promising discipline, only to radically change their opinions one year later. Once more, the pattern seems to be that lectures impart a negative impression of international law on students.

In summary, the results reveal that a regulatory myth shares the podium with a materialist myth, and while an increase in the second group does occur, the overall prevalence of the first is beyond question. At the same time, while students do seem to view international law as a useful professional skill - albeit with a remarkable fall after the subject had been taught -, most would prefer to keep the status quo in relation to how much of it should be taught at law schools. That is, there seems to be a climate of apathy - international law is nothing more than rules that may often be irrelevant that is not cured by learning.

\subsection{Perceptions of how international law is taught and its place in the curriculum}

Question 11 ("Considering your answer to Question 8, how do you understand the role of public international law in the legal curriculum?") was devised to put the above statistics into perspective. It invites the respondent to elaborate further on their objective judgment made in the previous question on whether international law would be worth taking if it were an elective. The aim is to garner the student's view on the place of international law in the legal curriculum. However, 
instead of sectioning in myths - which would be more suitable for comprehensive worldviews such as those expounded in Question 10 -, we will bring out the main ideas that surfaced from the responses piecemeal. Here, only responses from students who had already completed an elementary course in international law have been considered.

\subsection{International law as a second-class branch of law}

The first cluster is comprised of answers that cast international law as junior to the other disciplines taught during legal studies and challenge its pride of place among the courses listed as obligatory in the curriculum. One of the reasons frequently adduced was international law's isolation from legal practice in Brazil, as in U.3-XIII.4: "I cannot see the immediate usefulness of this subject for my professional future. It is very specific and I cannot envisage any future application in my professional project". U.3-XIV.2 went further: "Public International Law should not be a compulsory subject because it has no practical applicability for almost all students in the course. It is a question of pragmatism. It may even broaden the horizons of law students, but it has no place among mandatory modules such as civil and criminal law". Another common complaint among respondents in this group is the plethora of compulsory courses: "Law studies in Brazil are already overburdened with required modules. For this reason, I believe Public International Law should be optional, like several other courses that currently make up the curriculum at law schools" (U.3-XXIII/XXIV.14). For this group, international law ranks low in their order of preference. It is contrasted with municipal law, which has a multitude of direct applications. International law as a piece of the interdisciplinary puzzle

The next group of responses comprises students who see international law as one of the building blocks of legal education. This group is largely favourable to international law being a compulsory course in the legal curriculum. The keyword is interdisciplinarity; having that discipline as part of legal studies lies at the heart of an interdisciplinary curriculum, which for a sizable segment of the student population simply means being exposed to more legal subjects, and nothing outside the law. This can be seen in U.3-XXIII/
XXIV.7: "Public International Law is very important, because it is an integral part of an internationalist and multidisciplinary education". Others, such as P.3M.37, hail the fact that studying international law softens prejudices about normativity: "Public International Law broadens students' horizons on the concept of normative order: controlled by a supreme organ and abided by due to sanctions in case of non-compliance, which is not present in Public International Law". Finally, some responses, such as U.3-XI.17, remembered the mutual entanglement of all branches of law, and how everything appears to be affected by international law: "Today it looks like any legal discipline is somehow related to Public International Law. We cannot ignore its interdisciplinarity". This harks back to the complex-globalist myth in the previous section: globalisation has infiltrated every cell of the law, and even the domestic legal profession must come to terms with this new reality.

\subsection{Obsolete methods: students against the status quo}

Another voice heard from the answers was that of pedagogical criticism. Here, it is impossible to generalise: much is contingent on the individual lecturer's style and on the leeway given by the institution in terms of content and method. Therefore, while we still concentrate on the broader themes, due note will be taken of the universities from which each particular criticism springs. In general, students believe that international law is important in the curriculum, but are indignant at the way it is taught. One example is U.3-XII.13: "I think that having Public International Law in the curriculum is important. However, I do not think that the classes are taught well at the Faculty of Law".

An excessive emphasis on history was a common grievance, as seen in U.3-XI.14: "Public International Law classes dwell too much on historical aspects". This is repeated by M.3D.38: "I believe it is sufficient to have general coverage of the subject, although here at the Faculty of Law - in spite of our having the same professor who lectures at USP - the course has been too focused on historical contextualisation, and in a poor manner". One student (U.3-XI.30) was bolder and said that "Public International Law is a good revision of World History, but from a legal point of view". 
All this points to the fact that current teaching methods are disconnected from students' realities. U.3-XI.31 says, "I agree that the subject should be taught, but I do not agree with the way this has been done. I believe that it should be more problematised (with case studies) and more dynamic". This is seconded by U.3XIII.15: "Public International Law is well situated in the course, but it lacks a deeper study of the international context and relevant cases". The solution for some, including U.3-XII.19, is that "There should be more case studies". Another tool mentioned in the answers was moot courts or model United Nations (U.3-XII.9): "I believe that the method by which the subject is taught can be improved so as to make it more attractive. We could have, for example, simulations of international organs, which would be very interesting".

Perhaps the shallowness of the current approach was best captured by U.3-XIII.8: "At the Faculty of Law, Public International Law is poorly taught and poorly explained, and the professors give lectures that are too superficial, just like their books". Courses are completely divorced from the expectations of students, particularly when it comes to international law's uses in municipal law: "The course barely deals with the influence of Public International Law on the day-by-day routine of domestic law". For an audience composed of a majority of people who will not become professional international lawyers, bringing international law down from the exalted heights of the world of diplomacy is vital. Here, the focus should be on teaching how to argue international law before Brazilian courts, and how an international legal argument fits in with the argumentative practices prevailing in Brazilian jurisdictions. The practice of the judges and tribunals with regard to international law - in what cases international law is accepted by magistrates, what are the branches of international law absorbed more easily by legal practice, at what procedural moment is it more beneficial to invoke international law etc. - are the centrepiece of this approach that weds the international to the domestic in a seamless argumentative flow.

\subsection{Conclusion: international law teaching at a crossroads}

This section is a damning chronicle of, as well as a sobering alarm on, the current system. In spite of the tan- gible interest that students have in international law, both as part of the curriculum and as a utilisable professional skill, being out-of-touch with empirical questions (i.e. IR theory), following the methodological archaism (i.e. non-use of case studies, exclusive focus on the unilateral-passive lecture method), and being out-of-touch with the professional needs of students (i.e. no interface between international law and domestic law) are sounding the death knell for the discipline's prospects for the twenty-first century Brazilian law school in its current form. The bottom line is that innovation and creativity are sorely needed in a field that must reinvent itself. Reciting doctrinal mantras (be they positivist dogmatics or disciplinary history) as if to take shelter in the ivory tower of professional consensus only compounds the problem.

\section{Final conclusions}

We started with a highly pessimistic prediction: the prevalence of a "realist" myth about international relations among law students would give rise to a "pragmatic" approach to international law which would, in turn, engender scepticism and indifference towards its role in academia and practice. The evidence bore out the exact opposite: even though this trend does exist, it is not nearly as strong as we had foreseen. The plot instead begins with a climax - avid students intent on discovering a new universe of knowledge and culminates in an anti-climax - their disappointment with the reality of the subject as it is taught. Again, contrary to our expectations, international law classes had no meaningful effect on these perceptions. This is not say, of course, that international law is tedious: indeed, it would be no exaggeration to say that it is one of the most intellectually vibrant fields of law, especially in our era of incessant metamorphosis in world order. While trying not to venture too far into normative questions, one may legitimately ask: since the myth is unavoidable in any type of education we are ever surrounded by ideology -, how should we alter legal education in order to bring about different (i.e. more nuanced) myths about international law, and in so doing, revolutionise its role in the profession and the wider world?

Against this politically diverse background of myths, students speak in unison about the need to disman- 
tle the reigning calamity of outdated approaches to content and one-sided teaching methods. The quasiunanimity of the sovereigntist-regulatory myth betrays a formalistic conception of law, reinforced by a curriculum consisting mostly of black-letter law courses. One potential part of the answer, interdisciplinarity, would mean going beyond legal theory and braving the hitherto uncharted waters of anthropology, sociology, political science, and above all IR. Naturally, however, care should be taken not to overemphasise the (empirical) social sciences to the detriment of discourse and rhetoric studies, lest we slide back into realism through the back door by an excessive focus on causality. In any case, decisions such as these should be a pondered choice based on an informed debate. This would implicate a merge with other fields of knowledge. By reminding students that law is an open arena, we may hope to combat the emergence of the "absolute" myths described above that specifically treat international law solely as power or as morals.

Rethinking the role of law and legal practices and drafting a new legal curriculum are two sides of the same coin. It is, of course, a matter of choosing one path over another. This is another political battle that will have to be fought within the walls of the faculties of law from all over the country. Those unsatisfied with the status quo will have to forcefully put forth their own case, and we hope to have provided a basis for discussion.

HIIIIIIIIIIIIIIIIIIIIIIIIIIIIIII

\section{References}

Anzilotti, D. (1929). Cours de Droit International. Paris: Sirey.

Barthes, R. (1970). Mythologies. Paris: Seuil.

Brazilian Bar Association. (2009). Provimento $N^{\circ} 136$, de 19 de outubro de 2009. Available at: <http:// www.oab.org.br/noticia/18425/oab-publica-hoje-novas-diretrizes-para-o-exame-de-ordem-em-todo-o-brasil>. Accessed on 18 May 2016.

Brierly, J. (1944). The Outlook for International Law. Oxford: The Claredon Press.

Chandler, D. (2007). Semiotics: the basics. New York: Routledge.

Cunha, J. (2005). Direitos Humanos e Justiciabilidade: pesquisa no Tribunal de Justiça do Rio de Janeiro. SUR - Revista Internacional de Direitos Humanos, 2(3), 138-172.

Epstein, L.; Martin, A. (2014). An Introduction to Empirical Legal Research. New York: Oxford University Press.

Focarelli, C. (2012). International Law as a Social Construct. New York: Oxford University Press.

Folha de São Paulo. (2013). Ranking Universitário FoIha - Direito (2013). Available at: <http://ruf.folha. uol.com.br/2013/rankingdecursos/direito/> (in Portuguese). Accessed on 20 March 2016.

Foucalt, M. (1994). Dits et écrits, 1954-1988. Paris: Gallimard. Tome III: 1976-1979.

Goldstein, Jan. (1984). Foucault among the Sociologists: the 'Disciplines' and the history of the professions. History and Theory, 23(2), 170-192.

Grotius, H. (1925). The Law of War and Peace. Translation Francis Kelsey. New York: Carnegie Classics.

Kennedy, D. (1998). Legal Education as Training for Hierarchy. In: D. Kairys (ed.). The Politics of Law: a progressive critique. New York: Basic Books.

Kennedy, D. (2002). The Critique of Rights in Critical Legal Studies (pp. 178-227). In W. Brown, J. Halley (eds.) Left Legalism/Left Critique. Durham: Duke University Press.

Keohane, R. (1982). The Demand for International Regimes. International Organization, 36(2), 325-355.

Klabbers, J., Piiparinen, T. (2013). Normative Pluralism: An Exploration (pp. 13-34). In J. Klabbers, T. Piiparinen (eds.) Normative Pluralism and International Law. Cambridge: Cambridge University Press. 
Koskenniemi, M. (2005). From Apology to Utopia: the structure of international legal argument. Reissue with new epilogue. Cambridge: Cambridge University Press.

Koskenniemi, M. (2007). The Fate of Public International Law: between technique and politics. The Modern Law Review, 70(1), 1-30.

Koskenniemi, M. (2012). The Subjective Dangers of Projects of World Communty (pp. 3-13). In A. Cassese (ed.), Realizing Utopia: the future of international law. Oxford: Oxford University Press.

Lauterpacht, H. (1933). The Function of Law in the International Community. Oxford: Claredon Press.

Mearsheimer, J. (1994). The False Promise of International Institutions. International Security, 19(3), 5-49.

Mello, S (2004). Prefácio. In: A. Mattos. Direito Internacional Público. São Paulo: RT.

Miéville, C. (2005). Between Equal Rights: a Marxist theory of international law. Leiden/Boston: Brill.

Perreau-Sassine, A. (2010). Immanuel Kant on International Law (pp. 53-75). In S. Besson, J. Tasioulas (eds.), The Philosophy of International Law. Oxford: Oxford University Press.

Posner, R. (2010). How Judges Think. Cambridge: Harvard University Press, 2010.

Posner, E.; Sykes, A. (2012). International Law and the Limits of Macroeconomic Cooperation. Southern California Law Review, 86, 1025-1078.

Santos, B (1988). Uma Cartografia Simbólica das Representações Sociais : Prelegómenos a uma Concepção Pós-Moderna do Direito. Revista Crítica de Ciências Sociais, 24, 139-172.

Saussure, F. (1995). Cours de linguistique générale. Paris: Payot.

Steinberg, R (2013). Wanted - Dead or Alive : realism in international law (pp. 146-172). In J. Dunoff, M. Pollack (eds.). Interdisciplinary Perspectives on International Law and International Relations: the state of the art. Cambridge: Cambridge University Press.

Trindade, A (2002). O Direito Internacional em um Mundo em Transformação. Rio de Janeiro: Renovar.

Unger, R. (2005). Uma Nova Faculdade de Direito no Brasil. Cadernos FGV Direito Rio, 1, 113-131.

Weber, C. (2010). International Relations Theory: a cri- tical introduction. New York: Routledge.

Data de submissão/Submission date: 21.11.2016.

Data de aceitação para publicação/Acceptance date: 02.10.2017. 


\section{$7 \quad$ Appendix - Questionnaire (translated from Portuguese)}

The University of São Paulo is researching the perceptions and attitudes that law students from large institutions in São Paulo have about public international law and how it is taught. The objective of the project is to understand how students see this discipline with a view to developing means to make it more interesting to the Brazilian public. We would like to ask for your contribution by filling in the questionnaire below. Your answers will remain completely anonymous and will be used solely for the purposes of this research project.

1. Please indicate your gender:

2. Please indicate your age:

3. Have you ever done a legal internship, traineeship or clerkship?

a. Yes, in the public sector

b. Yes, in the private sector

c. No.

4. Do your career plans include any of the options below? If not, please leave it blank.

a. Public-sector legal professions

b. Private-sector legal professions

c. Diplomacy or international organisations

5. On a scale of one (completely disagree) to five (completely agree), how much do you agree with the following statement: "in general, public international law is an important factor in international relations"?

6. Which of the statements below best reflects your opinion?

a. Brazil should always comply with public international law. It is wrong to violate public international law, just as it is wrong to violate Brazilian laws. b. If it is not in Brazil's interests, Brazil should not comply with public international law.

7. Do you think public international law should be a mandatory subject in the law curriculum?

a. Yes, with more class hours than today (45 hours)

b. Yes, with the same number of class hours as today (45 hours)

c. Yes, with fewer class hours than today (45 hours)

d. No

8. If public international law were an optional module, would you choose to take it?

a. Yes

b. No

9. Considering your career aims, do you regard public international law as relevant to your professional future?

a. Yes

b. No

10. Considering your answer to question 5, how do you understand the role of public international law in international relations?

11. Considering your answer to question 8, how do you understand the role of public international law in the legal curriculum? 